
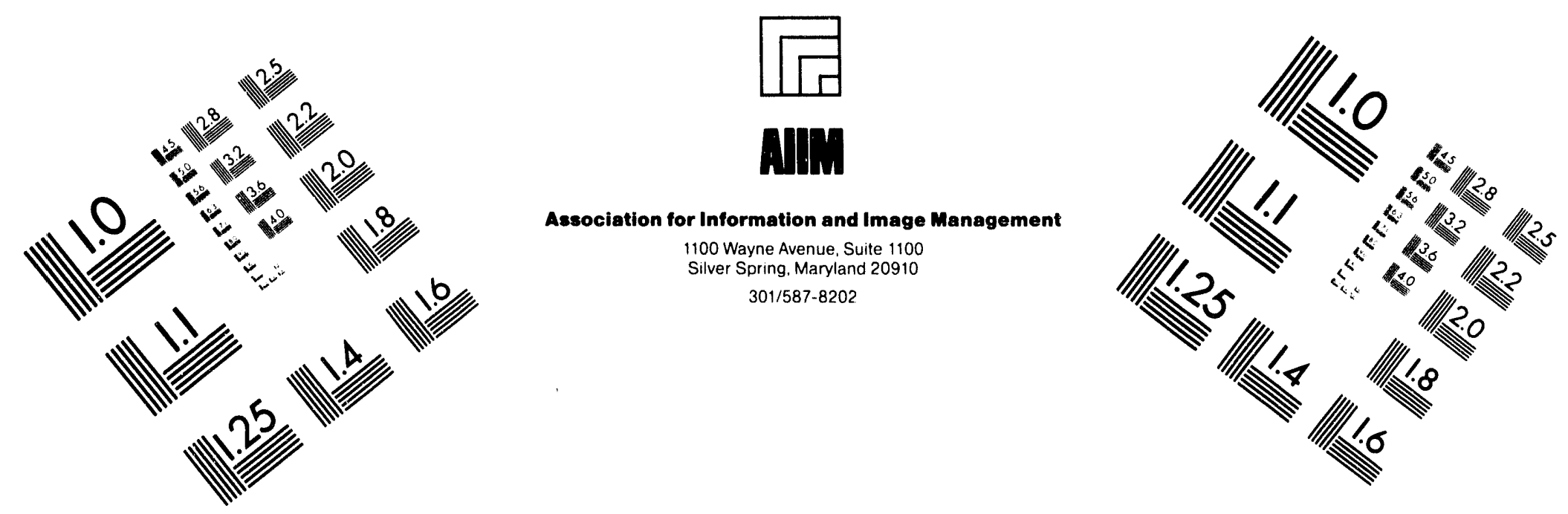

\title{
Centimeter
}

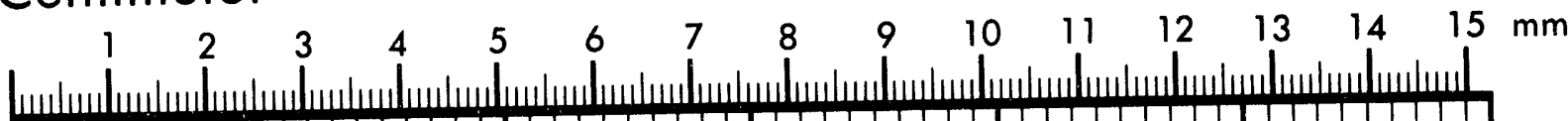

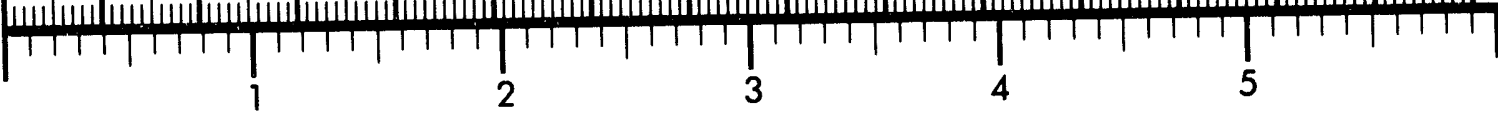
Inches
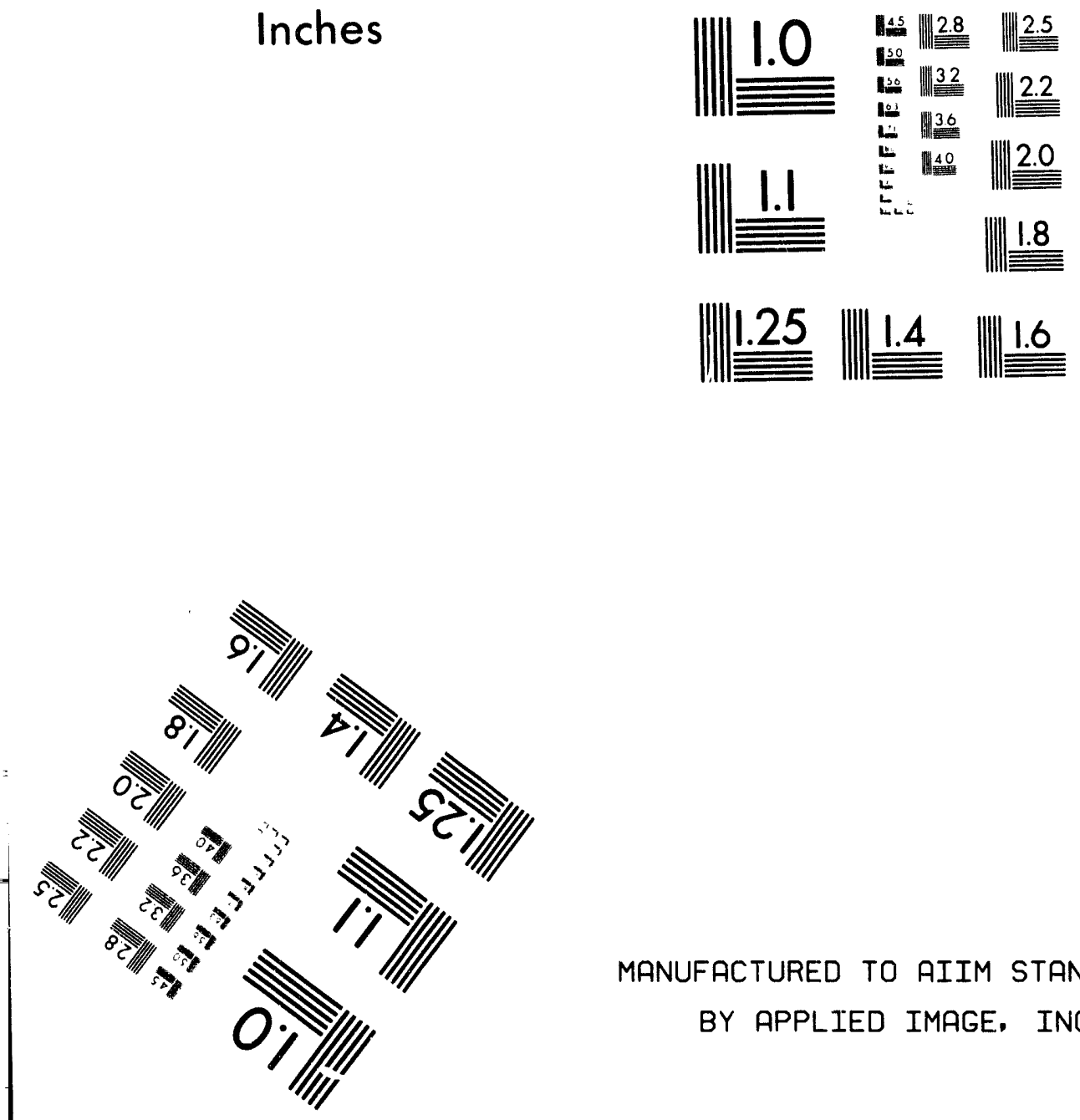

MANUFACTURED TO AIIM STANDARDS BY APPLIED IMAGE. INC.

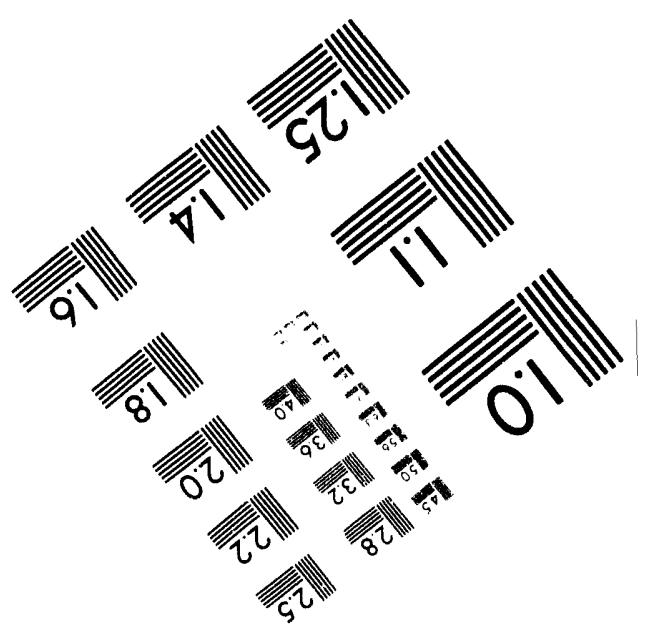



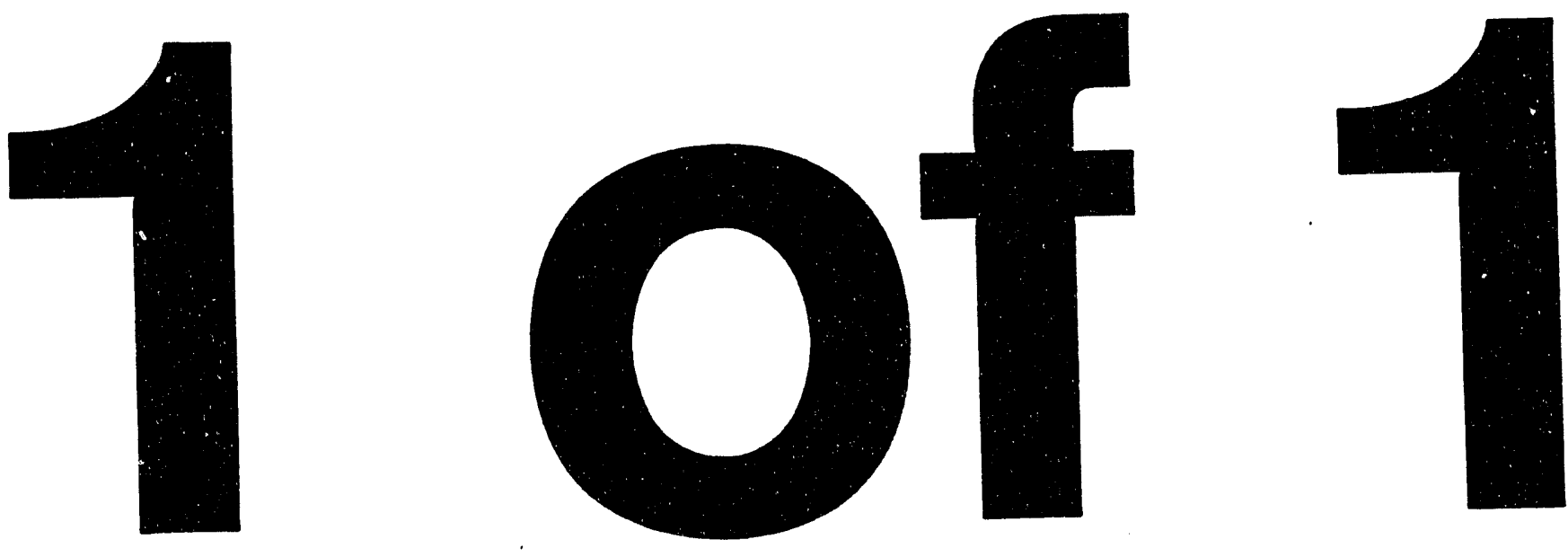


\section{Emissions of Air Toxics from Coal-Fired Boilers: Arsenic}

by M.H. Mendelsohn, H.S. Huang, and C.D. Livengood

Energy Systems Division,

Argonne National Laboratory, 9700 South Cass Avenue, Argonne, Illinois 60439

August 1994

Work sponsored by United States Department of Energy,

Assistant Secretary for Fossil Energy, Pittsburgh Energy Technology Center 


\section{Contents}

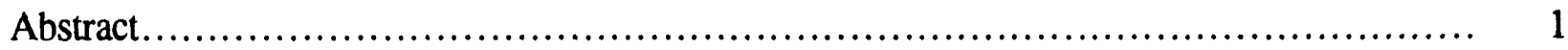

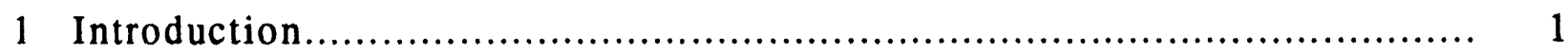

2 Concentrations of Arsenic in U.S. Coals ............................................ 4

3 Arsenic Emissions from Coal-Combustion Systems ................................. 8

3.1 Arsenic Emissions from Conventional Coal-Fired Combustors.................. 10

3.2 Arsenic Emissions from Fluidized-Bed Combustors .......................... 13

4 Influence of Flue-Gas-/Ash-Cleaning Devices on Arsenic Emissions ................. 16

4.1 Particulate-Collection Devices ................................................. 16

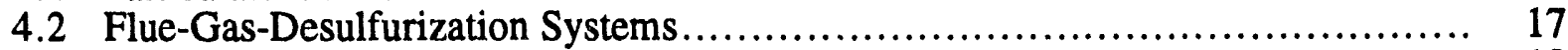

4.3 Control Technologies for Hazardous Waste Incinerators.......................... 18

4.4 New Processes for Control of Arsenic Emissions................................ 19

5 Review of Analytical Techniques for Various Arsenic Compounds.................... 20

5.1 Introduction.................................................................. 20

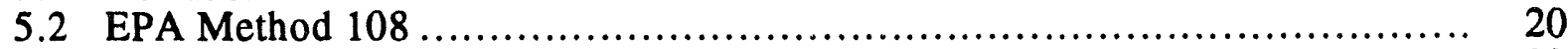

5.3 Alternative Methods for Arsenic Analysis...................................... 22

6 Conclusions and Recommendations ................................................ 25

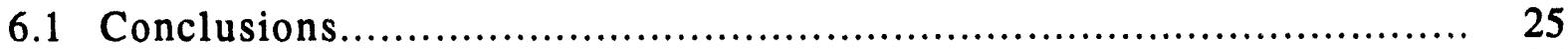

6.2 Recommendations............................................................... 26

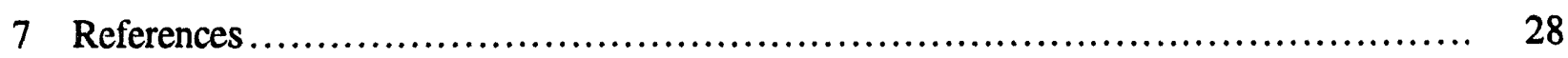

Figures

1 General Classification of Trace Elements during Coal Combustion ................. 9

2 Schematic of Method 5 Sampling Train ............................................. 21

3 Schematic Representation of the Plume-Simulating Dilution Sampler for Simultaneous Collection of Particle- and Gas-Phase Hazardous Air Pollutants

4 Keystone/NEA Hazardous Element Sampling Train for Coal-Fired Power Plants 


\section{Tables}

1 Concentrations of Arsenic in U.S. Coals ...................................... 5

2 Range of Arsenic Concentrations in Coal ....................................... 5

3 Concentrations of Arsenic in Coal by Region........................................... 6

4 Summary of Measured Arsenic Emissions from Bituminous-

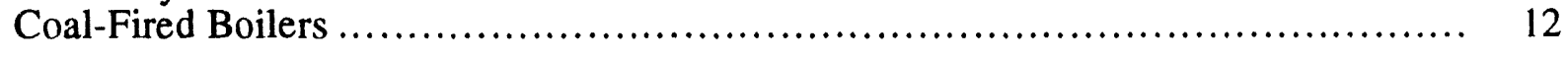

5 Summary of Measured Arsenic Emissions from Subbituminous-

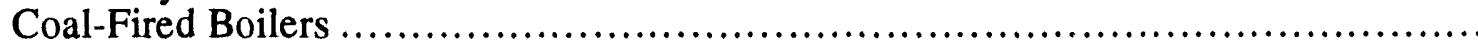

6 Summary of Measured Arsenic Emissions from Lignite-

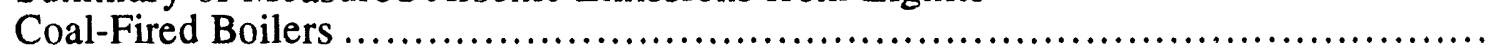

7 Summary of Removal Efficiencies of Arsenic from Emissions from Coal-Fired Boilers 


\title{
Emissions of Air Toxics from Coal-Fired Boilers: Arsenic
}

\author{
by
}

\author{
M.H. Mendelsohn, H.S. Huang, and C.D. Livengood
}

\begin{abstract}
Concerns over emissions of hazardous air pollutants (air toxics) have emerged as a major environmental issue; the authority of the U.S. Environmental Protection Agency to regulate such pollutants has been greatly expanded through passage of the Clean Air Act Amendments of 1990. Arsenic and arsenic compounds are of concern mainly because of their generally recognized toxicity. Arsenic is also regarded as one of the trace elements in coal subject to significant vaporization. This report summarizes and evaluates available published information on the arsenic content of coals mined in the United States, on arsenic emitted in coal combustion, and on the efficacy of various environmental control technologies for controlling airborne emissions. Bituminous and lignite coals have the highest mean arsenic concentrations, with subbituminous and anthracite coals having the lowest. However, all coal types show very significant variations in arsenic concentrations. Arsenic emissions from coal combustion are not well-characterized, particularly with regard to determination of specific arsenic compounds. Variations in emission rates of more than an order of magnitude have been reported for some boiler types. Data on the capture of arsenic by environmental control technologies are available primarily for systems with cold electrostatic precipitators, where removals of approximately 50 to $98 \%$ have been reported. Limited data for wet flue-gasdesulfurization systems show widely varying removals of from 6 to $97 \%$. On the other hand, waste incineration plants report removals in a narrow range of from 95 to $99 \%$. This report briefly reviews several areas of research that may lead to improvements in arsenic control for existing flue-gas-cleanup technologies and summarizes the status of analytical techniques for measuring arsenic emissions from combustion sources.
\end{abstract}

\section{Introduction}

Public concern over exposure to hazardous air pollutants (or air toxics) has emerged as one of the major environmental issues since the 1980s. ${ }^{1-8}$ Under Section 112 of the Clean Air Act (CAA) and subsequent amendments enacted by the U.S. Congress, the U.S. Environmental Protection Agency (EPA) is required to promulgate emission standards for those air pollutants that are not regulated under National Ambient Air Quality Standards. To date, EPA has prescribed actual emission standards for only seven substances and one source: arsenic, asbestos, benzene, beryllium, mercury, radionuclides, vinyl chloride, and coke oven emissions. In addition, EPA had previously determined that the low risks associated with radionuclide emissions from fossil-fuel 
power plants did not justify regulation under Section 112 of the CAA. Nevertheless, EPA may in the future reconsider the need for regulation under the so-called "residual risk" provisions of Section 112(f) in the latest (1990) amendments of the Clean Air Act.

The CAA Amendments of 1990 greatly expand EPA's rulemaking authority over hazardous air pollutants (HAPs). Section 112(b) of the 1990 CAA amendments includes a list of 189 chemicals, compounds, or groups of chemicals deemed by Congress to be HAPs that may be subjected to control. For stationary sources that emit 10 tons per year or more of any one of the listed pollutants, or 25 tons per year or more of any combined emissions, maximum available control technology (MACT) must be applied. By definition, MACT is at least as stringent as best available control technology (BACT) for similar sources. In addition, the new CAA Amendments represent a major shift in approach from regulation of HAPs by using health-based, substancespecific standards to regulation under technology-based standards applicable to categories of emission sources rather than to the substances themselves. The new amendments also state that the cost and feasibility of control, energy impacts, and environmental factors will be taken into consideration in the application of MACT.

Under the 1990 CAA Amendments, the EPA is directed to conduct a three-year study of the public health hazards from exposure to toxic air emissions from utilities and then to rep. irt to the Congress. (The completion date for this study has been extended to September 1994.) EPA can regulate such emissions only if limitations are appropriate on the basis of this study. The EPA is directed not to regulate these pollutants until the study is completed, and in no event will regulations be established sooner than . $\quad$ years nor later than five years after the legislation has been enacted.

Section 112(c)(1) of the 1990 CAA Amendments requires the EPA to publish, within one year of enactment of the 1990 Amendments, a list of categories of major and area sources emitting one or more listed HAPs. On July 16, 1992, EPA published an initial list of 174 industrial categories that produce HAPs and may be subjected to the agency's CAA regulations over the next 10 years. ${ }^{9}$ Those broad categories include fuel combustion, petroleum and natural gas production and refining, and waste incineration, among other stationary sources. In the Federal Register notice, EPA further stated that all categories may not be included in this initial listing. In fact, EPA specifically stated in the notice that sources defined as electric utility steam-generating units shall not be subjected to emission standards, pending the findings of the study mentioned above and subsequent listing and regulation. 9

In addition, under section 112(c)(9)(B), EPA may delete a category from the category list, based on petition of any person or on the EPA Administrator's own motion, upon a determination that (1) in the case of sources that emit HAPs that may result in cancer, no source in the category emits HAPs in quantities that may cause lifetime cancer risk greater than one in one million to the most exposed individual; or (2) in the case of sources that emit HAPs that may result in noncancerous adverse health effects or adverse environmental effects, emissions from no source in the category exceed a level adequate to protect public health with an ample margin of safety and no adverse environmental effects will result. However, in the latest Federal Register notice, no 
guidance or procedures have yet been provided by EPA for filing petitions to delete categories of sources found to cause no significant effects.

This report summarizes information available on arsenic concentration in U.S. coals, its emissions from coal-fired boilers, and the effectiveness of the control technologies that have been applied primarily for particulate and sulfur dioxide reduction. Also included in this report is a review of the analytical techniques that may be used in determining the concentration of the different forms of arsenic compounds. 


\section{Concentrations of Arsenic in U.S. Coals}

Information available before 1972 on trace elements in coal was thoroughly evaluated and compiled in a report prepared by Magee et al. 10 This report contains extensive earlier results published by researchers at the United State Geological Survey (USGS), the United States Bureau of Mines (USBM), and other organizations. However, as pointed out by Ruch and his coworkers at the Illinois State Geological Survey (ISGS), there is a serious shortcoming of these earlier studies:

Trace element investigations in coal prior to 1970 were based on analyses of hightemperature ash, which measure the oxides of the elements in the altered mineral matter. Although such investigations are valuable for estimating concentrations of refractive constituents, or elements of low volatility, they do not reliably measure total amounts of volatile elements in whole coal. ${ }^{11}$

The most comprehensive effort on the determinations of trace-element content in U.S. coals undoubtedly has been the coal geochemistry program of the USGS.12,13 In collaboration with the USBM and working independently, the USGS has analyzed more than 10,000 coal samples from numerous coal basins and fields in the United States. These samples are, for the most part, fullchannel or drill-core samples that represent a full coal bed. For determination of arsenic, wet chemical techniques (colormetric) were used initially, and instrumental neutron activation analysis (INAA) was used in later determinations. It was reported that no significant difference existed for arsenic determinations by these two methods. The detection limit by the colormetric method for arsenic was reported to be 1 part per million (ppm), with the precision being $10 \%$ if arsenic is greater than $10 \mathrm{ppm}$ and $100 \%$ if arsenic is less than $10 \mathrm{ppm}$; the INAA detection limit for arsenic is also $1 \mathrm{ppm}$, with a precision of $5 \%$. The extensive analytical results have been entered into the U.S. National Coal Resources Data Systems (NCRDS). These results, which have been evaluated and reported, ${ }^{10-20}$ are summarized below.

The mean concentrations of arsenic in U.S. coals by coal type are given in Table 1. As shown in Table 1, lignite and bituminous coal have the highest mean arsenic concentration, $22.8 \mathrm{ppm}$ and $20.3 \mathrm{ppm}$, respectively. These numbers may be considered as typical values for arsenic concentrations in U.S. coals, because the data from NCRDS were used in the statistical data reduction. Note, however, that the standard deviations all exceed the mean values, indicating large variations in the reported data. It should be noted, in addition, that most of the determinations of trace-element concentrations in coals were performed on raw drill-core coal samples from the coal beds. In using coal for energy generation, it has become a common practice that steam coals shipped to the end-users would have undergone a certain degree of preparation, which in most cases would result in decreased concentrations of certain elements in the coals. The ranges of reported concentrations of arsenic in bituminous, subbituminous, and lignite coals are given in Table 2, indicating that the bituminous coals have the greatest range of reported arsenic concentrations. 
TABLE 1 Concentrations of Arsenic in U.S. Coalsa

\begin{tabular}{lccr}
\hline & \multicolumn{2}{c}{$\begin{array}{c}\text { Arsenic } \\
\text { Concentration (ppm) }\end{array}$} & \\
\cline { 2 - 3 } Coal Type & Mean & $\begin{array}{c}\text { Standard } \\
\text { Deviation }\end{array}$ & $\begin{array}{c}\text { Number of } \\
\text { Samples }\end{array}$ \\
\hline Bituminous & 20.3 & 41.8 & $3,527.0$ \\
Subbituminous & 6.17 & 15.5 & 640.0 \\
Anthracite & 7.67 & 19.6 & 52.0 \\
Lignite & 22.8 & 138.0 & 183.0 \\
\hline
\end{tabular}

a Source: Reference 14.

TABLE 2 Range of Arsenic

Concentrations in Coala

\begin{tabular}{lc}
\hline Coal Type & $\begin{array}{c}\text { Arsenic } \\
\text { Concentration } \\
\text { Range (ppm) }\end{array}$ \\
\hline Bituminous & $0.02-357$ \\
Subbituminous & $0.1-16$ \\
Anthracite & $\mathrm{NA}$ \\
Lignite & $0.1-45$ \\
\hline
\end{tabular}

a Source: Reference 15. 
The concentrations of arsenic in U.S. coals also vary substantially by the geographic provinces and regions from which the coals are mined. It was reported that the geometric mean values for arsenic in coal from various U.S. geological provinces are, in descending order, $13.3 \mathrm{ppm}$ for Appalachian coal, $12.2 \mathrm{ppm}$ for Western Interior coal, $7.3 \mathrm{ppm}$ for Eastern coal, $3.9 \mathrm{ppm}$ for Gulf Coast coal, $3.5 \mathrm{ppm}$ for Northern Great Plains coal, $3.2 \mathrm{ppm}$ for Alaskan coal, and $1.8 \mathrm{ppm}$ for Rocky Mountain coal. ${ }^{11}$ The arsenic contents of coals from different geological regions are summarized in Table 3. As shown in Table 3, the arsenic content of western U.S. coal is significantly lower than that of coals from other U.S. regions. With the exceptions of the Fort Union and Wind River coal regions, western U.S. coal has less than $3 \mathrm{ppm}$ (geometric mean) arsenic content. In the East, coal from the southern Appalachian region has the highest mean arsenic concentration $(29 \mathrm{ppm})$, whereas the mean arsenic concentrations of coals from the central Appalachian region (Virginia, West Virginia, and eastern Kentucky) are substantially lower $(9.1 \mathrm{ppm})$. By contrast, the Pennsylvania anthracite and the Massachusetts/Rhode Island metaanthracite coals contain about $5 \mathrm{ppm}$ and $7 \mathrm{ppm}$ arsenic, respectively, which are less than that in the central Appalachian coals. However, coals (mostly bituminous coals) from the Appalachian

TABLE 3 Concentrations of Arsenic in Coal by Regiona

\begin{tabular}{|c|c|c|c|}
\hline \multirow[b]{2}{*}{ Coal Region } & \multicolumn{2}{|c|}{$\begin{array}{c}\text { Arsenic Concentration } \\
\text { (ppm) } \\
\end{array}$} & \multirow[b]{2}{*}{$\begin{array}{c}\text { Number of } \\
\text { Samples }\end{array}$} \\
\hline & $\begin{array}{l}\text { Geometric } \\
\text { Mean }\end{array}$ & $\begin{array}{l}\text { Standard } \\
\text { Deviation }\end{array}$ & \\
\hline Southern Appalachian & 29.4 & 4.5 & 650 \\
\hline Northern Appalachian & 14.2 & 3.1 & 689 \\
\hline Central Appalachian & 9.1 & 4.0 & 1,288 \\
\hline Mass./Rhode Island & 7.1 & $\cdots$ & 15 \\
\hline Fort Union & 6.6 & 2.7 & 198 \\
\hline Wind River & 4.9 & 3.6 & 24 \\
\hline Penn. anthracite & 4.7 & 2.8 & 61 \\
\hline Powder River & 2.4 & 3.3 & 487 \\
\hline Hams Fork & 2.3 & 2.3 & 20 \\
\hline Greenriver & 1.9 & 3.6 & 346 \\
\hline Southwestern Utah & 1.8 & 2.5 & 34 \\
\hline San Juan River & 1.5 & 2.7 & 86 \\
\hline Denver & 1.5 & 3.1 & 42 \\
\hline Unita & 1.2 & 3.0 & 194 \\
\hline Raton Mesa & 1.0 & 2.3 & 61 \\
\hline
\end{tabular}

a Source: Reference 12. 
region were also reported to have the greatest range of arsenic concentrations, from $0.5 \mathrm{ppm}$ to as high as $357 \mathrm{ppm} .15$

It has been reported that arsenic in U.S. coals, like many other trace elements in U.S. coals, is largely associated with the inorganic portion of the coal structure, principally pyrite. 12,20 In fact, it has been observed ${ }^{12}$ that there is a systematic increase in arsenic content with increases in pyritic sulfur, even though there is no systematic relation between arsenic concentration and total organic sulfur content, and there appears to be, at best, only a weak relation between arsenic concentration and ash content in coal. These observations strongly suggest that the concentrations of arsenic in coal could be significantly reduced through conventional or advanced physical coal preparation processes. Recent results reported by Akers and Dospoy 20 indicate that the arsenic level in physically cleaned U.S. coals could be reduced by about 30 to $50 \%$, compared to the arsenic levels in the as-received (before cleaning) parent coals. Because of their simplicity, physical coal-cleaning methods potentially could be the most cost-effective means for achieving a modest reduction of arsenic emissions from coal-fired systems. A systematic study, however, is warranted to fully investigate the effectiveness of the physical cleaning techniques for arsenic abatement. 


\section{Arsenic Emissions from Coal-Combustion Systems}

Distribution of trace elements in the combustion waste products is influenced by the type of boiler, operating conditions, and flue-gas-cleaning system, as well as by their concentrations in the coal. During combustion, trace elements in coal entering the furnace are released and partitioned between the bottom ash and the flue gas, which contains suspended fly-ash particles and the vapors of volatile elements, such as arsenic, boron, chlorine, and mercury. As the flue gas flows through and cools to 370 to $430^{\circ} \mathrm{C}$ in the convective heat-transfer section and to about $150^{\circ} \mathrm{C}$ in the air preheater, a portion of the less volatile elements condenses on the surface of the fly-ash particles. These vaporization and surface condensation mechanisms result in an inverse relationship of element concentration to size of the fly-ash particle. The smaller the particle, the higher is the concentration of volatile elements. 21,22

In response to environmental considerations, modern coal-fired boilers are equipped with particulate-control and flue-gas desulfurization devices. As the fly-ash-laden flie gas enters these devices, trace elements are further partitioned, and further condensation of the volatile elements occurs in the gas scrubbing systems. Elements on large fly-ash particles are retained by the particulate-collection devices; elements on small particles or in a vapor form, however, may escape from the control devices and be discharged into the atmosphere.

Three classifications of the trace elements, according to their partitioning and enrichment in a pulverized-coal-fired power plant, are used to characterize their emission: Classes I, II, and III. 15,23,24 Class I trace elements have low volatility even at high temperatures (1200 to $1600^{\circ} \mathrm{C}$ ); they have no tendency to concentrate in or on the fly-ash particles. Class II trace elements are vaporized and then condensed, tending to concentrate in or on the fly-ash particles. The bottom ash/slag, therefore, is depleted of the Class II trace elements. Class III trace elements remain mostly in the vapor phase and may be emitted from the stack even if the combustion system is equipped with a conventional flue-gas-cleaning device. Figure 1 shows Classes I, II, and III of the trace elements emitted during coal combustion.

Typical Class I elements include aluminum, calcium, and magnesium, and typical Class II elements include arsenic, cadmium, and selenium. To accommodate the observed phenomena that some elements behave as either Class I or Class II elements in different investigations, an additional classification has been proposed: Class I/II. Among the Class I/II elements are chromium, nickel, and vanadium. Typical Class III elements are mercury, boron, chlorine or hydrogen chloride, and fluorine or hydrogen fluoride.

For Class II and some Class III elements, the enrichment on smaller fly-ash particles has received considerable attention because these particles tend to have higher atmospheric mobilities and greater potential toxicity. Enrichment results from the larger specific surface area (per unit weight) on small particles, which allows greater amounts of vaporized elements to condense or be adsorbed on the surface. For example, it was reported ${ }^{24}$ that in some cases the more volatile elements, such as arsenic and selenium, were highly enriched in fly-ash particles smaller than 


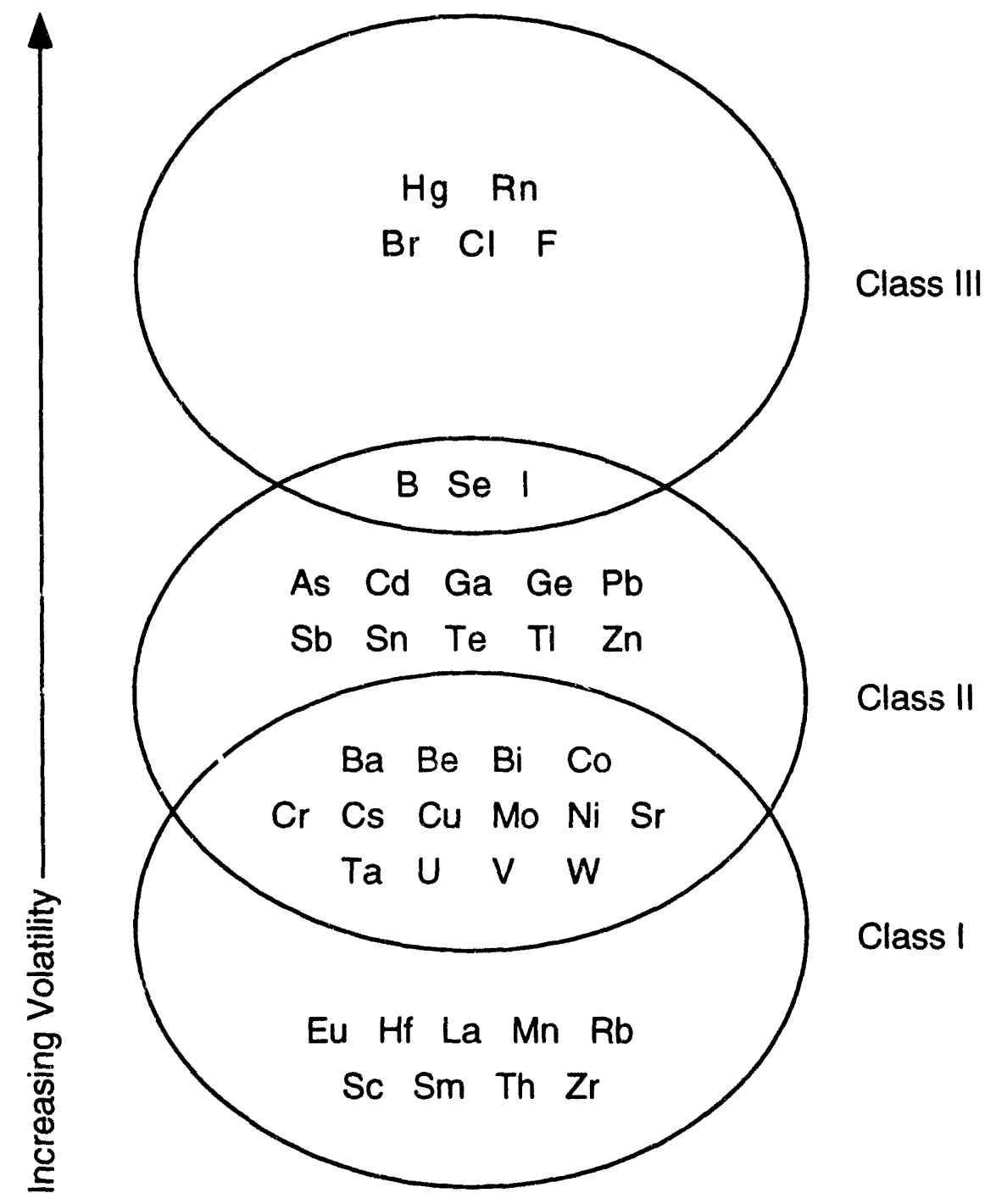

FIGURE 1 General Classification of Trace Elements during Coal Combustion

one micron by factors of more than an order of magnitude. In addition, as a result of this vaporization-condensation mechanism, a higher concentration of the Class II trace elements has been observed on the surfaces of a fly-ash particle than in the bulk concentration on the entire particle. ${ }^{23}$ This surface association of certain trace elements, such as arsenic and selenium, suggests that conventional bulk determinations of fly-ash particles provide a poor measure of the actual concentration of toxic trace elements to which the external environment is exposed.

To provide a simple but useful comparison, enrichment factors of trace elements on the fly ash or the concentrations of trace elements in the flue gas, relative to the trace elements in the coal, have been employed to describe the extent of enrichment. $15,23,24$ In order to eliminate the variability of such characteristics as moisture and ash content in coals, the enrichment factors are generally normalized to the concentration of a reference element, which is assumed to be nonvolatile under combustion conditions. The element aluminum (Al) is often used as the reference 
element. Other elements that have also been used as references include silicon ( $\mathrm{Si})$ and iron ( $\mathrm{Fe}$ ). The enrichment factor (EF) of an element (e) is related to the concentration (C) reference (ref) element as follows:

$$
\mathrm{EF}=\frac{\left(\mathrm{C}_{\mathrm{e}} / \mathrm{C}_{\mathrm{ref}}\right) \mathrm{fly} \text { ash }}{\left(\mathrm{C}_{\mathrm{d}} / \mathrm{C}_{\mathrm{ref}}\right) \operatorname{coal}}
$$

Class II elements have EFs greater than 1; higher EFs correspond to elements of higher volatility.

\subsection{Arsenic Emissions from Conventional Coal-Fired Combustors}

For conventional coal-fired boilers, the utility sector in the United States is dominated by dry-bottom pulverized-coal (PC) units. Wet-bottom PC and cyclone combustors are no longer sold because of the difficulty in meeting $\mathrm{NO}_{\mathrm{x}}$ emission standards; stoker boilers now account for only a small percentage of the total population of utility boilers. In the industrial sector, however, the stoker (mainly spreader type) and small dry-bottom PC units account for most of the coal-fired plants. This is similarly the case for larger boilers in the commercial/institutional sector; however, in this sector, oil- and natural-gas-fueled boilers dominate.

Because of the relatively low-to-moderate boiling points of the various arsenic (As) compounds (e.g., $\mathrm{AsCl}_{3}, 130.2^{\circ} \mathrm{C} ; \mathrm{As}_{2} \mathrm{O}_{3}, 457.2^{\circ} \mathrm{C} ; \mathrm{As}_{2} \mathrm{~S}_{2}, 565^{\circ} \mathrm{C} ; \mathrm{As}_{2} \mathrm{~S}_{3}, 707^{\circ} \mathrm{C}$ ) present in the coal, it is generally believed that a large portion of the arsenic content is vaporized during coal combustion and exits out of the furnace with flue gas and fly-ash particles. Reported results from many previous investigations indicated that only about $10 \%$ of the arsenic compounds in the coal would be retained in the bottom ash. 23,25 As discussed above, the state of the more volatile elements in the flue gas changes as the flue gas moves through the superheater, the economizer, the air preheater, and the flue-gas-cleaning devices The concentration of these elements increases as the fly-ash particle size decreases.

Little information exists on the vapor-phase arsenic concentration in the flue gas upstream of a collection device. Such vapor-phase arsenic would probably escape many of the existing particulate-collection devices and exit from the stack. A recent detailed investigation on traceelement emissions from a coal-fired utility boiler indicated that after the particulate-collection device, the portion of the arsenic in the vapor phase showed large variations, ranging from 1 to $52 \%$ of the total arsenic content in the flue gas. ${ }^{26}$ It was further stated by the authors that the percent of arsenic in the vapor phase is dependent upon either in-stack mass loading or the mass loading on the filter in the gas-sampling train. This assertion suggests that the low-end value might be a result of additional arsenic vapor/fly-ash (on the filter) reactions taking place when the flue gas was pulled through the sampling train. A similar observation was reported in an earlier study in which fly ash was used to remove $\mathrm{As}_{4} \mathrm{O}_{6}$ from the vapor, even when the vapor was not saturated at $200^{\circ} \mathrm{C} .27$ Reliable information on the distribution of arsenic between the vapor and particulate phases is needed, however, to determine whether particulate-control devices will be effective for arsenic control. 
In most of the prior investigations, only the total arsenic contert in the flue gas or in the fly-ash particles was measured; little quantitative information was developed on the speciation of individual arsenic compounds present in the flue gas and on the fine fly-ash particles. Because different arsenic species possess different degree of toxicity, this kind of information is needed in order to conduct a credible risk assessment of the arsenic emission from coal-combustion systems.

Gross mass emissions for a number of trace elements from coal- and oil-combustion sources in the utility, industrial, commercial/institutional, and residential sectors in the United States have recently been evaluated and summarized in an EPA report prepared by Radian Corporation. 14 It was stated that the utility and industrial sectors are the best characterized combustion sources, while relatively few data were available for the commercial/institutional and residential sectors. Therefore, information in Reference 14 for arsenic emissions from coal-fired utility and industrial boilers is extracted and, along with information from other reports, ${ }^{23-50}$ is presented in this subsection. It should be further noted, however, that "since insufficient data are available to develop statistical estimates of the accuracy of these emission factors, no estimate can be made of the error that could result when these factors are used to calculate emissions from any given facility." 14

The available information regarding measured arsenic emissions from coal-fired utility and industrial boilers is summarized in Tables 4 through 6 for bituminous (Table 4), subbituminous (Table 5), and lignite (Table 6) coals, respectively. ${ }^{13}, 23-50$ The data given in Tables 4 through 6 show considerable variations in gross arsenic emissions from large coal-fired boilers. No significant differences in arsenic emissions are exhibited between different boiler types or different end-user sectors. However, the available test data indicated that for combustion systems equipped with flue-gas-cleaning devices, significant reduction of arsenic emissions could be realized, because a significant portion of the arsenic is associated with the fly-ash particles. The effect of flue-gas-cleaning devices on reduction of arsenic emissions is discussed in Section 4.

If one assumes an average heating value of $29.1 \mathrm{~kJ} / \mathrm{g}(12,500 \mathrm{Btu} / \mathrm{lb})$ for U.S. bituminous coal, the mean arsenic concentration given in Taole 1 , and a $10 \%$ retention of arsenic in the bottom ash, the calculated uncontrolled arsenic emission would amount to $628 \mathrm{mg} / \mathrm{GJ}$. This value is somewhat greater than the high-end values summarized in Table 4. As stated above, most of the coals used in the utility boilers have been subjected to a certain degree of physical cleaning, which should result in a lower arsenic concentration in the coal, as compared to raw coal. Another possible explanation for the lower measured arsenic concentration could be that the vapor-phase arsenic concentrations were not adequately accounted for in most of the field investigations.

The effect of combustion modifications for $\mathrm{NO}_{\mathrm{x}}$ control on the emissions of trace elements from large coal-fired boilers was also investigated. ${ }^{29-31}$ In the tests with a tangentially fired utility boiler equipped with an electrostatic precipitator (ESP) for particulate control, it was concluded, based on the limited test data obtained, that low $\mathrm{NO}_{\mathrm{x}}$ operation appeared to have little effect on the partitioning of trace elements between bottom ash and fly ash and little effect on the segregation of trace species, within experimental error. ${ }^{29}$ 
TABLE 4 Summary of Measured Arsenic Emissions from Bituminous-Coal-Fired Boilers

\begin{tabular}{lc}
\multicolumn{1}{c}{ Boiler Type } & $\begin{array}{c}\text { Arsenic Emission } \\
\text { Range (mg/GJ) }\end{array}$ \\
\hline & \\
Utility & \\
Pulverized dry bottom & \\
Uncontrolled & $26.7-585$ \\
With mechanical collector (MC) & $8.2-851$ \\
With ESP & $0.2-104$ \\
With MC/2 ESPs in series & $0.1-5.7$ \\
With wet scrubber & $1.7-14$ \\
With ESP/wet scrubber & $14.9^{\mathrm{a}}$ \\
& \\
Pulverized wet bottom & No data available \\
Uncontrolled & $6.6-71$ \\
With ESP & $76.7^{\mathrm{a}}$ \\
With wet scrubber & \\
& \\
Cyclone combustor & $55.9-211$ \\
Uncontrolled & $2.7-12$ \\
With ESP & $350^{\mathrm{a}}$ \\
With wet scrubber & \\
Industrial & \\
Pulverized dry bottom & \\
Uncontrolled & \\
With mechanical collector (MC) & \\
With MC/wet scrubber & \\
With ESP & \\
Spreader stoker & \\
Uncontrolled & \\
With MC & \\
With MC/ESP & \\
With mechanical collector & \\
Overfeed stoker & \\
\hline
\end{tabular}

anly one data point available. 
TABLE 5 Summary of Measured Arsenic Emissions from Subbituminous-Coal-Fired Boilers

\begin{tabular}{lc} 
Boiler Type & $\begin{array}{c}\text { Arsenic Emission } \\
\text { Range (mg/GJ) }\end{array}$ \\
\hline Utility & \\
Pulverized dry bottom & \\
Uncontrolled & No data available \\
With ESP & $0.07^{\mathrm{a}}$ \\
With wet scrubber & $4.7^{\mathrm{a}}$ \\
Cyclone combustor & \\
Uncontrolled & $370^{\mathrm{a}}$ \\
With wet scrubber & $348^{\mathrm{a}}$ \\
Industrial & \\
Spreader stoker & \\
Uncontrolled & \\
With mechanical collector/ESP & $1.3-2.5$ \\
\hline
\end{tabular}

a Only one data point available.

\subsection{Arsenic Emissions from Fluidized-Bed Combustors}

Fluidized-bed combustors (FBCs) have attracted an increasing interest during the past decade. They are expected to be more commonly used in future, not only for the industrial sector but potentially also for utility applications. Fluidized-bed combustors (both atmospheric and pressurized modes) operate at a lower temperature $\left(800\right.$ to $\left.900^{\circ} \mathrm{C}\right)$ than conventional pulverizedcoal combustors. At this low temperature, the ash does not fuse and the carbon utilization is somewhat lower than normally experienced with the PC boiler. Also, in order to realize in-place capturing of sulfur dioxide generated during combustion, limestone or dolomite is used as the bed material. As a result of these features, the distribution of trace elements in the vapor phase or the solid-ash phase and in the bottom stream and the ash stream could be different from that observed in conventional coal combustors.

To date, only a limited number of tests has been conducted on trace-element emissions from small FBCs, mostly with non-U.S. coals. These results have been evaluated and discussed. 23 Several studies have reported that trace-element emissions from atmospheric fluidized-bed combustors (AFBCs) behave similarly to those from pulverized-coal combustion. Class II elements, such as arsenic and cadmium, were more concentrated in the finer-particle size fraction than in coarser fractions, as normally observed with pulverized-coal combustion. 
TABLE 6 Summary of Measured Arsenic Emissions from Lignite-Coal-Fired Boilers

\begin{tabular}{lc}
\multicolumn{1}{c}{ Boiler Type } & $\begin{array}{c}\text { Arsenic Emission } \\
\text { Range (mg/GJ) }\end{array}$ \\
\hline Utility & \\
Pulverized dry bottom & \\
Uncontrolled & \\
With mechanical collector & No data available \\
With ESP & $158-171$ \\
Cyclone combustor & $1.0^{\mathrm{a}}$ \\
Uncontrolled & \\
With mechanical collector & No data available \\
With ESP & $116^{\mathrm{a}}$ \\
With ESP/wet scrubber & $2.5^{\mathrm{a}}$ \\
Spreader stoker & $4.8^{\mathrm{a}}$ \\
Uncontrolled & \\
With mechanical collector & No data available \\
With ESP & $114^{\mathrm{a}}$ \\
Industrial & $2.3^{\mathrm{a}}$ \\
\hline & No data available \\
\hline Only one data point available. &
\end{tabular}

In one comparative study (summarized in Reference 23) of a 4-MWt vertical-shell AFBC and a 2-MWt vibrating-grate-stoker boiler, using the same fabric-filter unit and the same delivery of coal, little difference between the emissions was observed except for arsenic, which was ten times more concentrated in the stack gases from the AFBC unit than from the stoker. This was attributed to the difference in the stack gas temperature $\left(210^{\circ} \mathrm{C}\right.$ for $\mathrm{AFBC}$ and $180^{\circ} \mathrm{C}$ for stoker), suggesting that arsenic was probably released as $\mathrm{As}_{2} \mathrm{O}_{3}$, which sublimes at $193^{\circ} \mathrm{C}$. However, use of the fabric filter resulted in low arsenic stack emissions; in several cases, arsenic was undetectable for both the AFBC and the stoker units.

In another study (summarized in Reference 23) comparing trace-element emissions from a small stoker combustor $(3.8 \mathrm{MWt})$ and a small AFBC unit $(3.5 \mathrm{MWt})$, both equipped with a fabric filter and burning the same coal, the stack emissions from the AFBC had lower concentrations of arsenic, cadmium, and lead but a higher concentration of barium than did the stoker. In terms of EFs (normalized to aluminum), such Class II elements as arsenic, cadmium, and selenium were an order of magnitude lower in the fabric-filter ash from the AFBC than from the stoker. Additionally, vapor-phase arsenic emissions from the AFBC unit were found to be significantly lower than those from the stoker unit $\left(0-0.2 \mu \mathrm{g} / \mathrm{Nm}^{3} \mathrm{vs}\right.$. $\left.7.9-17.9 \mu \mathrm{g} / \mathrm{Nm}^{3}\right)$. 
However, additional comparable data from large-scale units are needed to substantiate this preliminary but favorable observation and to quantify the distribution of arsenic in the various outlet process streams. 


\section{Influence of Flue-Gas-/Ash-Cleaning Devices on Arsenic Emissions}

There are no reports of any specific measures taken at coal-fired boilers to control arsenic emissions. However, particulate-collection devices, such as ESPs and fabric filters, have been widely used for capturing fly-ash particles from coal-fired plants, and scrubbing systems have been used for controlling sulfur dioxide emissions from large boilers burning high- or mediumsulfur coals. These devices are known to also achieve a substantial reduction of low-volatility trace elements that are mostly associated with the fly-ash particles. A portion of the arsenic present in the flue gas may be in the condensed phase, and so the effectiveness of these devices in reducing arsenic emissions from large coal-fired boilers is discussed in this section.

\subsection{Particulate-Collection Devices}

Particulate controls for coal-fired boilers are extensively discussed in an Argonne report ${ }^{51}$ and in the proceedings of the Particulate Control Symposiums cosponsored by the EPA and the Electric Power Research Institute (EPRI). 52 There are basically four types of particulate control devices: ESPs, fabric filters (or baghouses), wet scrubbers, and mechanical collectors (e.g., cyclones). Properly designed ESPs can achieve overall removal efficiencies of $99.5 \%$ or greater, but the efficiencies vary with particle size. The collection efficiency is lower for respirable particles (smaller than $10 \mu \mathrm{m}$ ) and can even be lower than $90 \%$ for particles in the size range of $0.1-1 \mu \mathrm{m}$.

ESPs. Both cold and hot electrostatic precipitators are widely used in coal-fired boilers. ESP control of arsenic emissions varies from 50 to $97.6 \%$. For efficiency, systems are frequently equipped with an ESP and a mechanical collector in series.

Fabric filters. Fabric filters are inherently high-efficiency particulate collectors, even with variable-inlet particulate loading in the flue gas. Typical removal efficiencies are usually greater than $99.5 \%$, and overall removal efficiencies of $99.7-99.8 \%$ have been reported. For particles in the size range of $0.1-1 \mu \mathrm{m}$, the efficiency can be $97-99 \%$. However, no information has been obtained from the open literature on the arsenic emissions from U.S. coal-fired boilers equipped with fabric filters for particulate control.

Wot scrubbers. The highly efficient venturi and moving-bed wet scrubbers are widely used in coal-fired power plants. The efficiency of the venturi scrubbers depends on the pressure drop achieved, about $99 \%$ for both 2 - and $1-\mu \mathrm{m}$ particles at $5.5 \mathrm{kPa}$ (22 in. of water) and $15 \mathrm{kPa}$ (60 in. of water). The moving-bed wet scrubbers also can achieve a removal efficiency of $99 \%$ for particles greater than $2 \mu \mathrm{m}$. For smaller particles $(0.1-1 \mu \mathrm{m})$, the collection efficiency of wet scrubbers drops rapidly to below $50 \%$. 
Mechanical collectors. Cyclones are the most widely used mechanical collectors, but they have a low overall efficiency: for large particles, less than $90 \%$ for one cyclone and less than 95\% for two cyclones in series. For small respirable particles (less than $5 \mu \mathrm{m}$ ), the efficiency is as low as $60 \%$. Hence, this type of particulate control is often used (1) as a means of reducing the overall particulate loading into a more efficient collector or (2) in less-turbulent combustors, such as the chain-grate stokers.

The number of paired data points (inlet and outlet) for arsenic emissions from coal-fired boilers on any given control device in the United States is extremely limited. Data on calculated removal efficiencies are summarized in Table 7, which was extracted from a recent EPA report. 14 Of the 32 test runs included in summarizing these data, 26 (or $81 \%$ ) are from boilers equipped with ESPs.

\subsection{Flue-Gas-Desulfurization Systems}

Flue-gas-desulfurization (FGD) systems are designed mainly for sulfur dioxide control However, these systems also are effective in particulate control. Two types of flue-gasdesulfurization systems generally have been used for large coal-fired boilers: wet FGD and spraydryer FGD systems. The wet FGD system is typically placed downstream of a particulatecollection device, and it can be used for coals having a range of sulfur contents. Some of the older wet FGD units might also have been designed for simultaneously controlling particulates. In comparison, the spray-drying reaction chamber in the dry FGD system is located upstream of the particulate-collection device. To date, dry spray-dryer FGD systems have been used mainly with coals having low to medium sulfur contents. No reports have yet been published on the effectiveness of spray-dryer-based FGD systems for arsenic removal in coal-combustion plants.

TABLE 7 Summary of Removal Efficiencies of Arsenic from Emissions from Coal-Fired Boilers

\begin{tabular}{lcc}
\hline & \multicolumn{2}{c}{$\begin{array}{c}\text { Arsenic Removal } \\
\text { Efficiency }(\%)\end{array}$} \\
\cline { 2 - 3 } Control Device & Average & Range \\
\hline & & \\
Cyclone/multiclone & 51.0 & $25.8-70.8$ \\
ESP & 87.5 & $50.0-97.6$ \\
2 ESPs in series & 99.6 & $99.2-99.97$ \\
FGD scrubber & 51.5 & $5.8-97.3$ \\
ESP/FGD scrubber & 98.9 & $\cdots$ \\
\hline
\end{tabular}

Source: Reference 14. 
Spray-dryer-based FGD systems, however, have been used for arsenic removal in flue gas from waste incineration plants. Two recent reports give arsenic-removal efficiencies of $99.9 \%$ for a spray-dryer absorber followed by pulse-jet fabric filters in Studstrup, Denmark, ${ }^{53}$ and $99.5 \%$ for a spray-dryer/fabric-filter facility in Malmo, Sweden. ${ }^{54}$ However, two data points have been found for units equipped with wet FGD scrubbers in the United States. Table 7 shows FGD arsenic removal efficiencies.

The average removal efficiency of $51.5 \%$ for an FGD scrubber in Table 7 must be viewed with caution, both because it is based on only two test runs and because the two test runs differed so widely. The one value of $98.9 \%$ obtained for an ESP/FGD scrubber combination suggests that perhaps the higher value of $97.3 \%$ (top of range) obtained for an FGD scrubber alone may be closer to the true value. This is also supported by a recently reported value of $100 \%$ arsenic removal with a wet-lime FGD scrubber in Germany. ${ }^{54}$ The average control efficiency of $51 \%$ measured for a mechanical precipitator (cyclone/multiclone) is consistent with theory.

\subsection{Control Technologies for Hazardous Waste Incinerators}

The spray-drying scrubbing system has been successfully applied to waste incineration systems for controlling (mainly) hydrogen chloride. Heavy metals, such as arsenic, are often present in the flue gases from hazardous waste (HW) incinerators in concentrations of up to several hundred milligram per standard cubic meter $\left(\mathrm{mg} / \mathrm{m}^{3}\right)$. Spray-dryer absorption (SDA) has been developed for HW incinerators by AVS Niro Atomizer of Denmark and has been used in Europe since 1982. This same company has used SDA systems for municipal solid waste (MSW) incinerators in Europe since 1986. Data published in $1984^{55}$ showed that arsenic emissions from an HW incinerator in Nyborg, Denmark, removed $93-98 \%$ of total arsenic by using an SDA system with an ESP collector and $95-98 \%$ with a baghouse particulate collector. Data published in $1988^{56}$ gave removals of arsenic from two lines of MSW incinerators in Leverkusen, Germany, as 99.7\% and $97.6 \%$ with the use of an SDA system with ESP collectors. In Canada, a test program has been performed with two pilot-scale pollution control systems attached to an MSW in Quebec City. 57 One system used a dry spray of hydrated lime powder along with a fabric filter, while the other system used a wet-lime slurry similar to an SDA system along with a fabric filter. Arsenic removal in the particulate phase was greater than $99.9 \%$ for both pollution control systems. These removals, however, do not appear to include any vapor-phase species.

In the United States, published data are somewhat more limited. Recently, information has become available on removal efficiencies for various control technologies used with HW incinerators. For example, Rizeq et al. ${ }^{58}$ summarized data obtained from four $\mathrm{HW}$ incineration facilities. They reported arsenic removal efficiencies of about $99 \%$ and $100 \%$, respectively, for venturi/wet-scrubber and baghouse/wet-scrubber removal technologies. Also, Murowchick and Rice have published results from an HW incinerator in Illinois. ${ }^{59}$ They found arsenic removal efficiencies of greater than $99 \%$ using a spray-dryer/fabric-filter control technology. 


\subsection{New Processes for Control of Arsenic Emissions}

Dry absorption processes have been tested mostly in laboratory environments for arsenic removal at high temperatures. Wouterlood and Bowling 27 discuss the dry absorption of arsenious-oxide $\left(\mathrm{As}_{4} \mathrm{O}_{6}\right)$ vapors by various substances. The most economically attractive absorbent studied was an unidentified activated carbon. Removal efficiency varied from $95-100 \%$ for three different activated carbons. More recently, Srinivasachar et al. 60 described a laboratory experiment to remove vapors formed over solid $\mathrm{As}_{2} \mathrm{O}_{3}$ in a gas stream containing hydrochloric acid and sulfur dioxide. They found an arsenic removal efficiency of about $85 \%$ by using an unidentified absorbent. Finally, Balling and Hein 61 report that by the addition of $2 \%$ limestone to coal, gaseous arsenic in the flue gas was decreased from 600 to $100 \mu \mathrm{g} / \mathrm{Nm}^{3}$. 


\section{Review of Analytical Techniques for Varlous Arsenic Compounds}

\subsection{Introduction}

Arsenic is widely distributed in the biosphere. It occurs in soils, sea water, fresh water, and groundwater. Atmospheric arsenic occurs through burning of fossil fuels and smelting of nonferrous ores; it also occurs naturally through volcanism and derives from the oceans by bubble bursting. 62 It has also been found in terrestrial plants, marine animals, and algae. Arsenic occurs in both inorganic and organic forms. Of the inorganic forms, arsine $\left(\mathrm{AsH}_{3}\right)$ is highly toxic, and arsenite $\left(\mathrm{AsO}_{2}{ }^{-}\right)$is accepted as being more toxic than arsenate $\left(\mathrm{AsO}_{4}{ }^{-3}\right){ }^{63}$ The toxicity of organic arsenic compounds also varies; those of natural origin appear to be nontoxic or of low toxicity, while some synthetic compounds, particularly those containing arsenic (III), are very toxic. Generally, it would seem that compounds of arsenic (III) are considerably more toxic than those of arsenic (V). 64

A number of methods have been described in the literature for measuring low levels of arsenic in biological and environmental samples. For a full discussion of various methods for measuring biological and environmental samples for different arsenic compounds, see the Morita and Edmonds (1992) article. ${ }^{62}$ In the coal-fired boiler literature, the most common methods used are inductively coupled plasma argon spectroscopy, atomic absorption spectroscopy (AAS), optical emission spectroscopy, differential pulse anodic stripping, neutron activation analysis (NAA), spark source mass spectroscopy (SSMS), and X-ray fluorescence (XRF). The EPA reference method for arsenic is Reference Method 108, found in the Code of Federal Regulations, 40, Part 61, Appendix B; this method is based on AAS. 65

\subsection{EPA Method 108}

EPA Method 108 specifies the principles for sampling and analysis as follows: "Particulate and gaseous arsenic emissions are withdrawn isokinetically from the source and collected on a glass mat filter and in water. The collected arsenic is then analyzed by means of atomic absorption spectrophotometry." A sampling train similar to the Method 5 train of 40 CFR Part 60 , Appendix A, is used as shown in Figure 2. Sampling procedure for arsenic is the same as that given in Method 5, except for maintaining a temperature of 107 to $135^{\circ} \mathrm{C}$ around the filter and maintaining isokinetic sampling flow rates below $28 \mathrm{~L} / \mathrm{min}$. (The remainder of the procedure need not be detailed here.) Method 108 does note that the lower limit of flame atomic absorption spectrophotometry is $10 \mu \mathrm{g} \mathrm{As} / \mathrm{mL}$. Two alternative methods are described for lower-concentration samples, a vapor generator procedure and a graphite furnace procedure, although the lower limits of these two methods are not mentioned. 


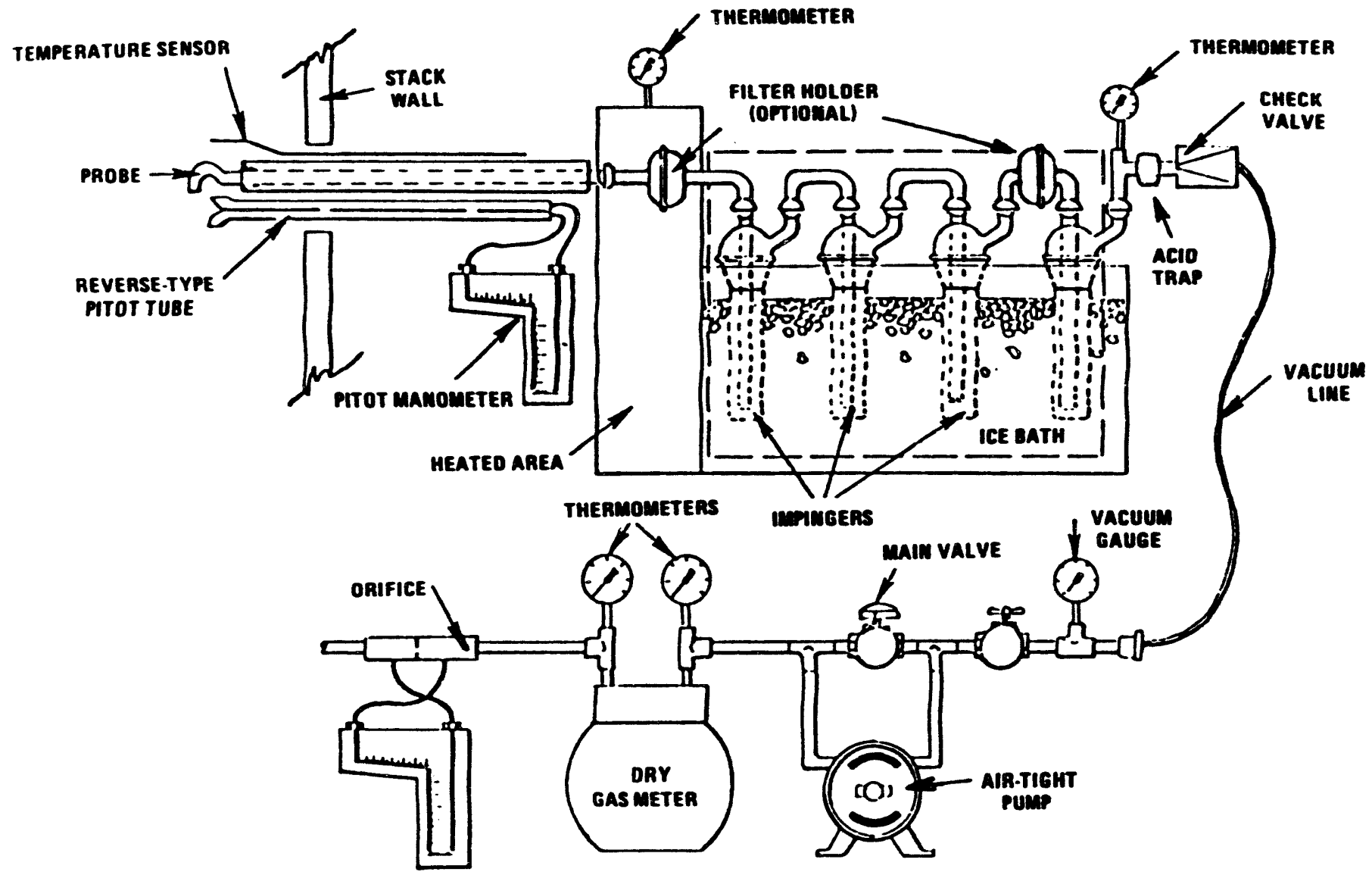

$N$

FIGURE 2 Schematic of Method 5 Sampling Train 


\subsection{Alternative Methods for Arsenic Analysis}

Of the analytical methods mentioned above, AAS is the most sensitive for measurement of arsenic in solution, having a detection limit of $0.2 \mathrm{ppb} .14$ NAA and SSMS can detect $0.2 \mathrm{ng}$ and $0.06 \mathrm{ng}$ of solid arsenic, resuectively. ${ }^{14}$ Recently, the detection limit of XRF for solid arsenic has been given as $0.3 \mathrm{ng} / \mathrm{cm} .2,66$ Arsenic (III) and arsenic (V) species may also be determined in solution by spectrophotometric methods. An improved method for spectrophotometric determination of arsenic has recently been reported. ${ }^{67}$ This chemical enhancement method can detect both arsenic (III) and arsenic (V) concentrations as low as $0.03 \mu \mathrm{g}$ in a final volume of $25 \mathrm{~mL}$. This detection limit is about 10 times lower than standard spectrophotometric methods.

Among recently reported improvements for arsenic detection, Cooper has described a new sampler called a plume simulating dilution sampler (PSDS) and a new hazardous element sampling train (HEST), which are useful for the sampling and detection of many trace-element emissions. 66 Keystone/NEA's PSDS is illustrated in Figure 3. This configuration has been used for the simultaneous collection of both gas- and particle-phase hazardous air pollutants. An isokinetic sample is drawn into the system through a cyclone preseparator and a heated stainless-steel transfer tube. The hot stack gas is drawn from the transfer tube into the instrument and blending module, where it is surrounded by cooled nitrogen dilution gas. After blending and mixing, the diluted gas stream passes through an aging chamber. The particle- and gas-phase samples are sampled downstream of this section. Particle-phase trace elements (including arsenic) are analyzed by XRF and NAA. Gas-phase components (including arsenic) can be sampled and measured by the charcoal trap method. 66

Keystone/NEA's HEST is illustrated in Figure 4. The sampling train uses a standard instack filter probe, which draws in an isokinetic sample that passes through a filter pack. The first filter collects the particulate phase. The second filter is a charcoal-impregnated filter (CIF) used to collect gas-phase elements. A second CIF is a backup that can be analyzed if there is concern for breakthrough. The stack gas passes through the filter pack and on to a series of impactors to remove water vapor before the flow and volume are monitored. The filter pack is separated from the probe at the end of a sampling period, then capped and returned to the laboratory for analysis. Particulate arsenic is analyzed by nondestructive XRF. An arsenic detection limit 60 times lower is claimed for the HEST method as opposed to the EPA tentative Method $29\left(5 \mathrm{ng} / \mathrm{m}^{3}\right.$ with HEST vs. $300 \mathrm{ng} / \mathrm{m}^{3}$ for the EPA tentative Method 29). 66 Tentative Method 29 is based on EPA Method 5 stack-sampling probes and impinger trains, but it adds potassium permanganate in sulfuric acid impingers to extract mercury and hydrogen peroxide-nitric acid impingers (in front of the permanganate impingers) to remove other metals besides mercury. 


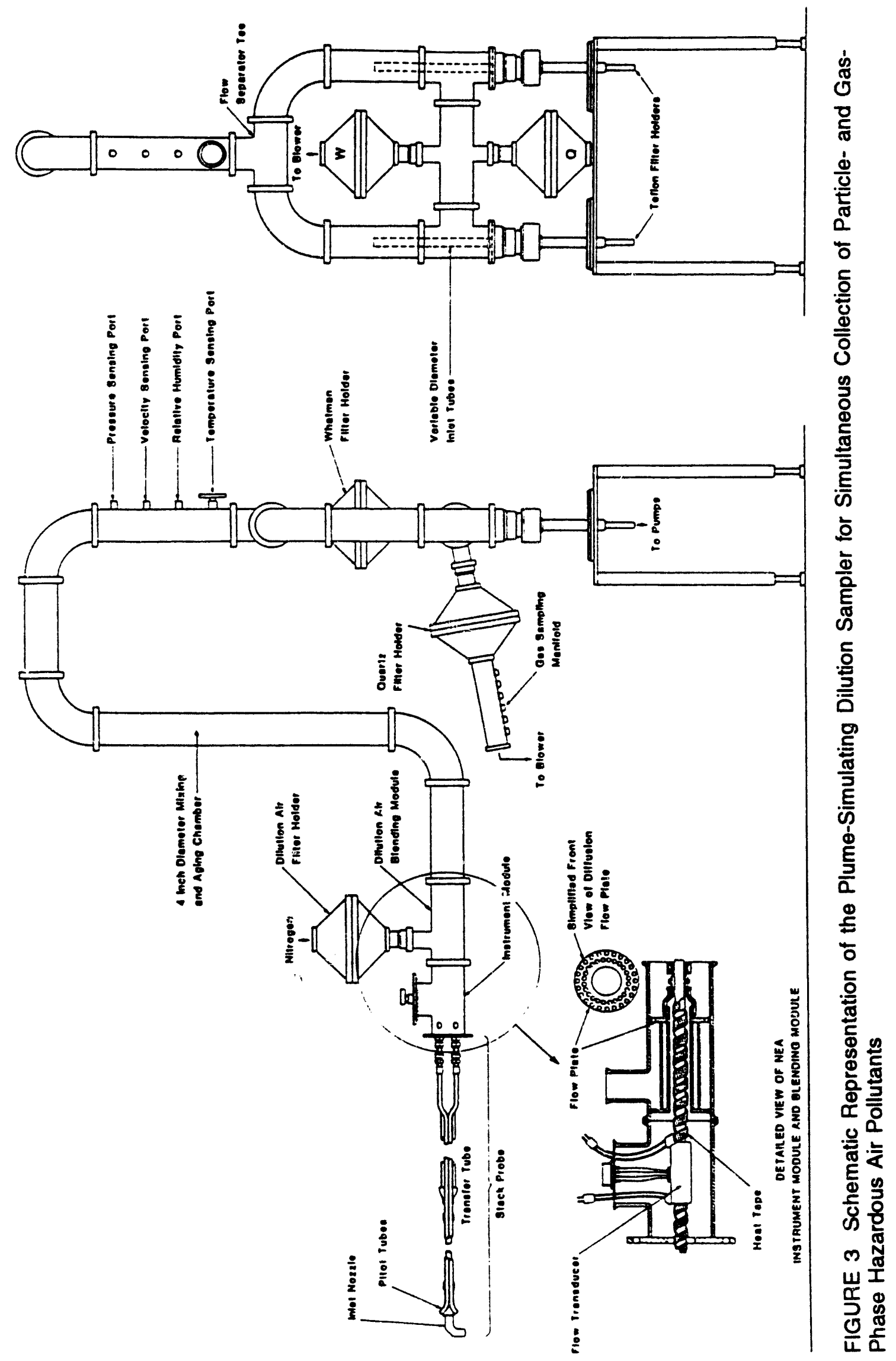



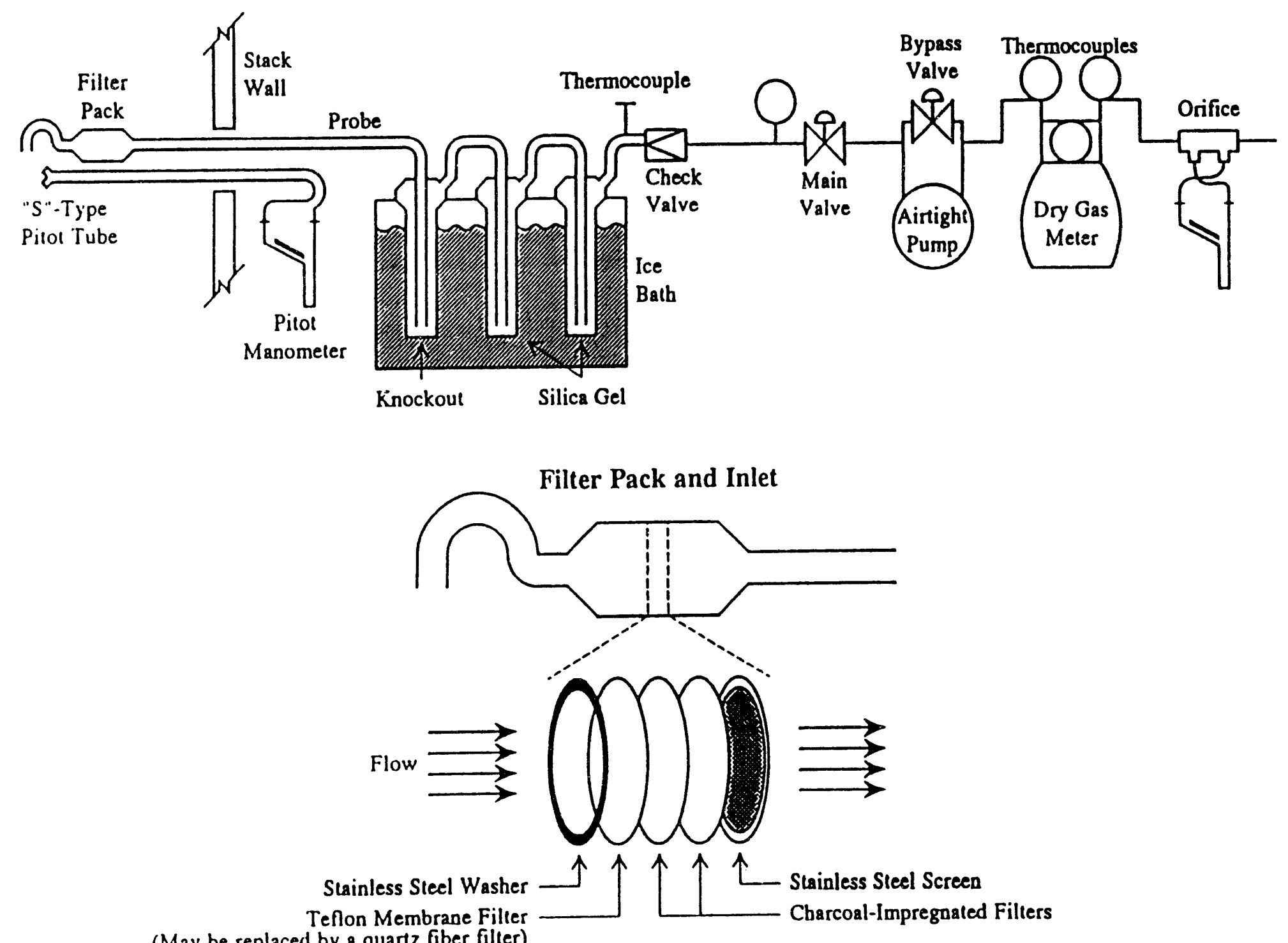

(May be replaced by a quartz fiber filter)

FIGURE 4 Keystone/NEA Hazardous Element Sampling Train for Coal-Fired Power Plants 


\section{Conclusions and Recommendations}

\subsection{Conclusions}

The emission of trace elements, such as arsenic, mercury, and other compounds, from coal combustion is generally dependent on a number of factors: the initial concentrations in the coal and their form; the combustion and heat-exchange conditions (temperature, residence time, and others); and the installation and availability of various pollution-control devices. The quality of the available information on arsenic concentrations in U.S. coals and arsenic emissions from large coal-fired utility and industrial boilers, with or without pollution-control devices, is much better than that of the available data for mercury concentrations in U.S. coal and its emissions from coalcombustion plants. ${ }^{68}$ Based upon the available information, the following conclusions are drawn:

1. Arsenic concentrations in U.S. coals show significant variation with coal types and with the geological regions where the coal is mined. The exact forms in which arsenic exists in U.S. coals, however, are less well understood. It has been reported that arsenic in many U.S. coals is principally associated with the mineral constituents in coal, especially the pyrite. If this is the case, then physical coal-cleaning techniques could be a cost-effective way to achieve moderate removal of arsenic content in these coals.

2. During combustion, about $10 \%$ of the arsenic in coal was found to be retained in the bottom ash; the balance of the arsenic was vaporized and became part of the flue gas. As the flue gas cools while flowing through the heat-exchange devices, a portion of the arsenic vapor probably is condensed The degree of condensation is strongly dependent on the arsenic concentration in the flue gas and the operating conditions of the heat-exchange devices. Very little information exists on the distribution of arsenic in either the vapor phase or the condensed phase.

3. As a result of the vaporization/condensation mechanism, arsenic enrichment on fine fly-ash particles has been observed. However, the exact forms of the arsenic in the flue gas and on the fly-ash particles are not well known. Since each arsenic compound has a different degree of toxicity, this information is needed in assessing the potential impact of arsenic emissions on the environment.

4. A major portion of the information available for arsenic emissions from coalfired boilers is associated with plants equipped with cold ESPs. The effectiveness of the ESPs for arsenic emission control was in the range of 50 to $97.6 \%$. 
5. No published information is yet available on the effectiveness of fabric filters for control of arsenic emissions from coal-fired boilers. This device, because of its high removal efficiency for fine particulates, probably would show removal efficiencies for arsenic emissions equal to or better than those of the ESPs.

6. Limited data on wet FGD systems indicated that the reported effectiveness of this device for arsenic control ranged widely, from 6 to $97 \%$. Reported results, however, indicated that a combination of ESP and a wet FGD system, or a combination of two ESPs in series, could achieve about $99 \%$ arsenic removal.

7. No information has been reported on the effectiveness of the spray-dryer-based FGD system for arsenic removal in coal-combustion plants. This FGD system, however, has shown very high removal efficiencies for arsenic in waste flue gas from waste incineration plants, ranging from 95 to $98 \%$ for systems equipped with ESPs and up to $99 \%$ for systems with fabric filters.

8. The dry absorption process (using different sorbents) has been demonstrated in laboratory-scale units and in a field test for efficient removal of arsenious-oxide vapors at high temperatures. This process has proved to be very effective in the lab and in preliminary field tests.

9. No continuous emission monitoring (CEM) system is available for arsenic concentrations in stack gas. However, a recently developed hazardous element sampling train claims arsenic detection limits 60 times better than that achieved with the tentative EPA method 29, which employs modified EPA Method 5 stack-sampling trains. ${ }^{69}$

\subsection{Recommendations}

In light of the foregoing conclusions, the following investigations are recommended:

1. Investigate the effectiveness of physical and chemical coal-cleaning methods for the removal of constituent arsenic from U.S. coals.

2. Conduct experiments, as part of the U.S. Department of Energy's studies on air toxics from coal-fired plants, to characterize arsenic emissions from plants equipped with fabric filters, wet FGD systems, and spray-dryer FGD systems. Also, closely monitor the results of the studies being conducted by the Electric Power Research Institute on air toxics from coal-fired power plants. 
3. Continue the development of techniques for improved removal of fine fly-ash particulates from coal-combustion flue gases. This should also result in significant reduction of the toxic trace elements, because many of the toxic trace elements, including arsenic, are associated with fine fly-ash particulates in the flue gas.

4. Conduct additional field experiments to test arsenious-oxide removal from flue gas through the use of dry absorption processes.

5. Evaluate the performance of the flue-gas hazardous element sampling methods that have been developed or are under development. 


\section{References}

1. Swain, E.B., et al., 1992, "Increasing Rates of Atmospheric Mercury Deposition in Midcontinental North America," Science 257:784-787, Aug. 7.

2. Laznow, J., and R. Gerstle, 1992, "New Rules Tighten Control of Hazardous Air Pollutants," Hazamat World 5(1):36-37.

3. U.S. Department of Energy, Office of Environmental Guidance, Air/Water/Radiation Division, 1991, Summary of The Clean Air Act Amendments of 1990 and 'reliminary Analysis of Their Implications for DOE, March.

4. Electric Power Research Institute, 1991, "New Focus on Air Toxics: The Clean Air Act," EPRI Journal, pp. 4-13, March.

5. ENSR Consulting and Engineering, 1988, Air Quality Handbook, 10th ed., Acton, Mass., June.

6. Schroeder, W.H., et al., 1987, "Toxic Trace Elements Associated with Airborne Particulate Matter: A Review," Journal of the Air Pollution Control Association 37(11):1267-1285.

7. van Hook, R.I., and W.D. Shults (editors), 1977, Effects of Trace Contaminants from Coal Combustion, U.S. Department of Energy, Energy Research and Development Administration report, ERDA-77-64, June.

8. Heit, M., 1977, A Review of Current Information on Some Ecological and Health Related Aspects of the Released Metals into the Environment Associated with the Combustion of Coal, U.S. Department of Energy, Energy Research and Development Administration report, HASL-320, June.

9. Office of the Federal Register National Archives and Records Administration, 1992, Code of Federal Regulations, 57(137):31576-31592, July.

10. Magee, E.M., et al., 1973, Potential Pollutants in Fossil Fuels, U.S. Environmental Protection Agency report, EPA-R2-73-249, June.

11. Ruch, R.R., et al., 1974, Occurrence and Distribution of Potentially Volatile Trace Elements in Coal: A Final Report, Illinois State Geological Survey report, Environmental Geology Notes no. 72, Aug. 
12. Coleman, S.L., and L.J. Bragg, 1990, "Distribution and Mode of Occurrence of Arsenic in Coal," in Recent Advances in Coal Geochemistry, Geological Society of America Special Paper 248, pp. 13-26.

13. Finkelman, A.C., et al., 1991, Bibliography of Publications Containing Major, Minor, and Trace Elements Data from the National Coal Resources Data System, U.S. Geological Survey Open-File report no. 91-123, Feb.

14. Radian Corporation, 1989, Estimating Air Toxics Emissions from Coal and Oil Combustion Sources, U.S. Environmental Protection Agency report, EPA-450/2-89-001, April.

15. White, D.M., et al., 1984, Correlation of Coal Properties with Environmental Control Technology Needs for Sulfur and Trace Elements, U.S. Environmental Protection Agency report, EPA-600/7-84-066, June.

16. Kuhn, J.K., et al., 1980, Abundance of Trace and Minor Elements in Organic and Mineral Fractions of Coal, U.S. Environmental Protection Agency report, EPA-600/7-80-003, Jan.

17. Gluskoter, H.J., et al., 1977, Trace Elements in Coal: Occurrence and Distribution, Illinois State Geological Survey report, Circular 499.

18. Swanson, V.E., et al., 1976, Collection, Chemical Analysis, and Evaluation of Coal Samples in 1975, United States Geological Survey report 76-468.

19. Mezey, E.J., et al., 1976, Fuel Contaminants, Vol. I: Chemistry, U.S. Environmental Protection Agency report, EPA 600/2-76-177a, July.

20. Akers, D.J., and R. Dospoy, 1992, "Use of Coal Cleaning to Reduce Air Toxics," presented at the Annual Meeting of the Society for Mining, Metallurgy, and Exploration, Phoenix, Ariz., Feb. 24-27 (Preprint Number 92-113).

21. Fisher, G.L., et al., 1977, "Size-Dependence of the Physical and Chemical Properties of Coal Fly Ash," Preprints of Fuel Chemistry Division, ACS 22(4):149-155, March.

22. Davison, R.L., et al., 1974, "Trace Elements in Fly Ash: Dependence of Concentration on Particle Size," Environmental Science and Technology 8(12):1107-1113.

23. Smith, I.M., 1987, Trace Elements from Coal Combustion: Emissions, International Energy Agency (IEA) Coal Research Report, IEACR/01, June. 
24. Markowski, G.R., and R. Filby, 1985, "Trace Element Concentration as a Function of Particle Size in Fly Ash from a Pulverized Coal Utility Boiler," Environmental Science and Technology 19(9):796-804.

25. Huang, H.S., 1977, Argonne National Laboratory, unpublished information, Sept.

26. Germani, M.S., and W.H. Zoller, 1988, "Vapor-Phase Concentrations of Arsenic, Selenium, Bromine, Iodide, and Mercury in the Stack of a Coal-Fired Power Plant," Environmental Science and Technology 22(9):1079-1085.

27. Wouterlood, H.J., and K.M. Bowling, 1979, "Removal and Recovery of Arsenious-Oxide from Flue Gas," Environmental Science and Technology 13(1):93-97.

28. Lyon, W.S., 1977, Trace Element Measurements at the Coal-Fired Steam Plant, CRC Press, Cleveland, Ohio.

29. Higginbotham, E.B., et al., 1981, Combustion Modification $\mathrm{NO}_{x}$ Controls for Utility Boilers. Volume I: Tangential Coal-Fired Unit Field Test, U.S. Environmental Protection Agency report, EPA-600/7-81-124A, July.

30. Sawyer, J.W., et al., 1981, Combustion Modification $N O_{x}$ Controls for Utility Boilers. Volume II: Pulverized-Coal Wall-Fired Unit Field Test, U.S. Environmental Protection Agency report, EPA-600/7-81-124B, July.

31. Lim, K.J., et al., 1980, Environmental Assessment of Utility Boiler Combustion Modification $\mathrm{NO}_{x}$ Controls: Volume 1. Technical Results, U.S. Environmental Protection Agency report, EPA-600/7-80-075a, April.

32. Zielke, R.L., et al., 1982, Field Study to Obtain Trace Element Mass Balances at Konston Steam Plant, U.S. Environmental Protection Agency report, EPA-600/7-82-042, May.

33. Scinto, L.L., et al., 1981, Source Test and Evaluation Report: Cane Run Unit No. 6 Louisville Gas and Electric Co. (Final Report, Sept. 79-June 81), U.S. Environmental Protection Agency report, EPA-600/7-81-134, Aug.

34. Edwards, L.O., et al., 1980, Trace Metals and Stationary Conventional Combustion Processes: Volume 1. Technical Report, U.S. Environmental Protection Agency report, EPA-600/7-80-155A, Aug.

35. Evers, R., et al., 1980, Field Study to Obtain Trace Element Mass Balances at a Coal-Fired Utility Boiler, U.S. Environmental Protection Agency report, EPA-600/7-80-171, Oct. 
36. Leavitt, C., et al., 1980, Environmental Assessment of a Coal-Fired Controlled Utility Boilers, Final Report, U.S. Environmental Protection Agency report, EPA-600-7-80-086, April.

37. Mann, R.M., et al., 1978, Trace Elements of Fly Ash: Emissions from Coal-Fired Steam Plants Equipped with Hot-Side and Cold-Side Electrostatic Precipitators for Particulate Control, U.S. Environmental Protection Agency report, EPA-900/4-78/008, Dec.

38. Kaakinen, J.W., et al., 1975, "Trace Element Behavior in Coal-Fired Power Plants," Environmental Science and Technology 9(9):773-779.

39. Kaakinen, J.W., and R.M. Jordan, 1974, "Determination of a Trace Element Mass Balance for a Coal-Fired Power Plant," Proceedings of the First Annual National Science Foundation Trace Contaminant Conference, pp. 165-184, W. Fulkerson et al. (editors), CONF 73082, USAEC Technical Information Center, Oak Ridge, Tenn.

40. Klein, D.H., et al., 1975, "Pathways of Thirty-Seven Trace Elements through Coal-Fired Power Plant," Environmental Science and Technology 9(10):973-979.

41. Mesich, F.G., et al., 1975, Coal Fired Power Plant Trace Element Study, Vol. I; A Three Station Comparison, National Technical Information Services report, PB-257 293, Sept.

42. Radian Corp., 1975, Coal Fired Power Plant Trace Element Study, Vol. II, National Technical Information Services report, PB-283 278, Sept.

43 Ensor, D.S., et al., 1976, Determination of the Fractional Efficiency, Opacity Characteristics, Engineering and Economic Aspects of a Fabric Filter Operating on a Utility Boiler, Electric Power Research Institute report, EPRI FP-297, Nov.

44. Burlingame, J.O., et al., 1981, Field Tests of Industrial Coal Stokers Fired Boilers for Inorganic Trace Element and Polynuclear Aromatic Hydrocarbon Emissions, U.S. Environmental Protection Agency report, EPA-600/7-81-167, Oct.

45. Surprenant, N.F., et al., 1981, Emissions Assessment of Conventional Stationary Combustion Systems: Volume V: Industrial Combustion Sources, U.S. Environmental Protection Agency report, EPA-600/7-81-003C.

46. McCurley, W.R., et al., 1979, Source Assessment: Dry Bottom Industrial Boilers Firing Pulverized Bituminous Coal, U.S. Environmental Protection Agency report, EPA-600/2-79019E, June. 
47. Leavitt, C., et al., 1978, Environmental Assessment of Coal- and Oil-Firing in Controlled Industrial Boilers, U.S. Environmental Protection Agency report, EPA-600/7-78-164A, Aug.

48. Leavitt, C., et al., 1978, Environmental Assessment of Coal- and Oil-Firing in Controlled Industrial Boilers, U.S. Environmental Protection Agency report, EPA-600/7-78-164B, Aug.

49. Cato, G.A., 1976, Field Testing: Trace Element and Organic Emissions from Industrial Boilers, U.S. Environmental Protection Agency report, EPA-600/2-76/006B, Oct.

50. Smith, E.O., et al., 1982, Full-Scale Scrubber Characterization of Conesville Unit 5, Electric Power Research Institute report, EPRI-CS/2525, Aug.

51. Southern Research Institute, 1977, Environmental Control Implications of Generating Electric Power from Coal, Technology Status Report, Appendix E: A Review of Technology for Control of Fly Ash Emissions from Coal In Electric Power Generation, Argonne National Laboratory report, ANL/ECT-3, App. E, Dec.

52. Electric Power Research Institute, 1990, Proceedings: Eighth Particulate Control Symposium, Electric Power Research Institute report, EPRI-GS-7050, vols. I and II, Nov.

53. Felsvang, K., et al., 1992, "Control of Air Toxics by Dry FGD Systems," presented at the Power-Gen '92 Conference, Orlando, Fla., Nov. 17-19.

54. Clarke, L.B., and L.L. Stoss, 1992, "Trace Element Emissions from Coal Combustion and Gasification," Draft Report, International Energy Agency (IEA) Coal Research, London, England, March.

55. Moller, J.T., and O.B. Christiansen, 1984, "Dry Scrubbing of Hazardous Waste Incinerator Flue Gas by Spray Dryer Absorption," presented at the Annual Meeting of the Air Pollution Control Association, San Francisco, Calif., June 24-29.

56. Donnelly, J.R., et al., 1988, "Joy/Niro MSW Incinerator FGC Systems European Experience - An Update," presented at the Annual Meeting of the Air Pollution Control Association, Dallas, Texas, June 19-24.

57. Environment Canada, 1986, The National Incinerator Testing and Evaluation Program: Air Pollution Control Technology, Environment Protection Series, 3/UP/2, Sept. 
58. Rizeq, R.G., et al., 1992, "Engineering Analysis of Metals Emissions from Hazardous Waste Incinerators," presented at the Annual Meeting of the Air and Waste Management Association, Kansas City, Mo., June 21-26.

59. Murowchick, P.S., and B.L. Rice, 1992, "Metals Control Efficiency Test at a Dry Scrubber and Fabric Filter Equipped Hazardous Waste Incinerator," presented at the Annual Meeting of the Air and Waste Management Association, Kansas City, Mo., June 21-26.

60. Srinivasachar, S., et al., 1992, "Heavy Metal Transformations and Capture during Incineration," presented at the Annual Meeting of the Air and Waste Management Association, Kansas City, Mo., June 21-26.

61. Balling, L., and D. Hein, 1989, "DeNO ${ }_{x}$ Catalysts for Different Furnace Types and Fuels: Development, Testing, Implementation," Dechema Monograph 118:55-72.

62. Morita, M., and J.S. Edmonds, 1992, "Determination of Arsenic Species in Environmental and Biological Samples," Pure and Applied Chemistry 64(4):575-590.

63. Venugopal, B., and T.D. Luckey, 1978, Metal Toxicity in Mammals 2, Plenum Press, N.Y.

64. Knowles, F.C., and A.A. Benson, 1983, Trends in Biochemical Sciences 8:178.

65. Office of the Federal Register National Archives and Records Administration, 1992, Code of Federal Regulations, 40, July.

66. Cooper, J.A., 1992, "Recent Advances in Sampling and Analysis Coal-Fired Power Plant Emissions For Air Toxic Compounds," presented at the Annual Coal Preparation, Utilization, and Environmental Control Contractors Conference, Pittsburgh, Pa., July 27-30.

67. Palanivelu, K., et al., 1992, "A Chemical Enhancement Method for the Spectrophotometric Determination of Trace Amounts of Arsenic," Talanta 39(5):555-561.

68. Huang, H.S., C.D. Livengood, and S. Zaromb, 1991, Emissions of Airborne Toxics from Coal-Fired Boilers: Mercury, Argonne National Laboratory report, ANL/ESD/TM-35.

69. U.S. Environmental Protection Agency, 1989, unpublished information, Sept. 


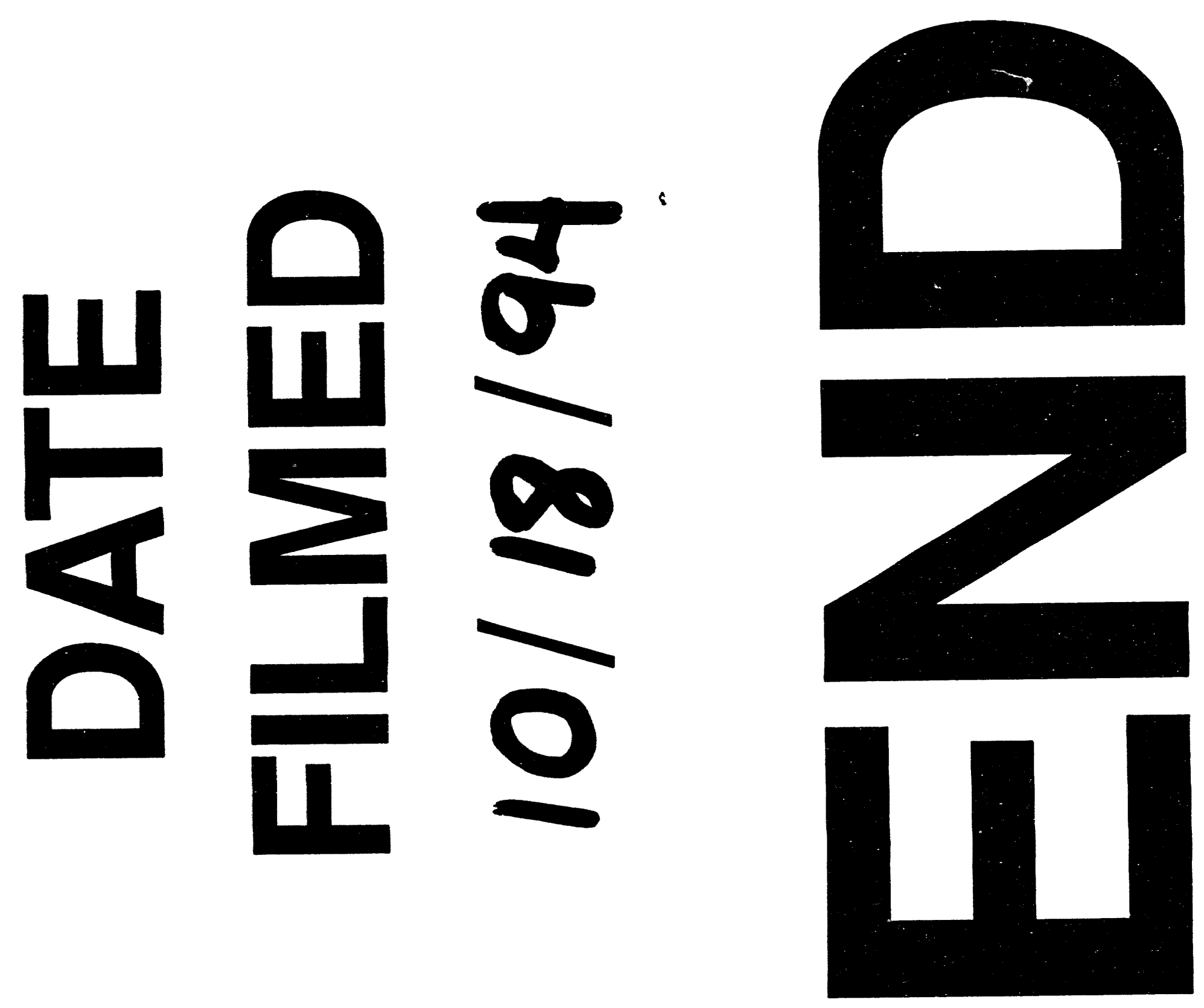




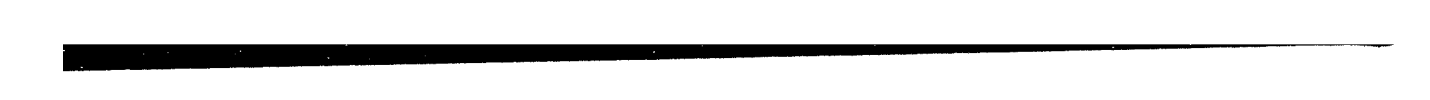

-
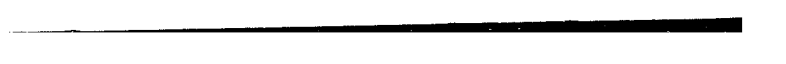